\title{
ZAŠTITA USTAVNIH JAMSTAVA POREZNIH OBVEZNIKA U POREZNIM POSTUPCIMA
}

\author{
UDK: 342 (4) \\ Primljeno: 15. 12. 2017. \\ Pregledni rad
}

\begin{abstract}
Ostvarenje i zaštita ustavnih jamstava poreznih obveznika u ovom radu proučavani su kroz postupke odnosno pravne puteve koje porezni obveznici imaju pravo pokretati u svrhu zaštite svojih Ustavom zajamčenih prava i sloboda. Upravna i sudska praksa istražena je putem analize objavljene prakse Europskog suda za ljudska prava i Ustavnog suda Republike Hrvatske. Rad je u tom smislu podijeljen u tri glavna dijela. Prvo se istražuje primjena Europske konvencije za zaštitu ljudskih prava i temeljnih sloboda u poreznim stvarima, a potom slijedi posebni osvrt na zahtjeve protiv Hrvatske koji su podneseni pred Europskim sudom. Zadnji dio rada odnosi se na analizu prakse Ustavnog suda u poreznim stvarima od 1. siječnja 2015. do 1. rujna 2017. godine koja obuhvaća 85 odluka Ustavnog suda.
\end{abstract}

Ključne riječi: ustavna jamstva, porezni obveznik, porezni postupak, Ustavni sud Republike Hrvatske, Europski sud za ljudska prava

\section{UVOD}

Porezno pravo tradicionalno se smatra područjem izvršavanja suverenosti država. Međutim, porezno pravo uključuje i pravo poreznih obveznika da ih se oporezuje na način koji je u skladu s ustavnim jamstvima a da se njihova prava ne žrtvuju zbog interesa državne blagajne i učinkovite provedbe poreznog nadzora. ${ }^{1}$ Ustavna jamstva, u koja osobito pripadaju ljudska prava i temeljne slobode, univerzalna su, pa se tako odnose i na porezne obveznike. To znači da porezna tijela trebaju ostvarivati svoje fiskalne ciljeve u skladu s ustavnim jamstvima poreznih obveznika. Pojam ustavnih prava za potrebe istraživanja u ovome radu podrazumijevat ce se prema pravnim stajalištima Ustavnog suda Republike Hrvatske (dalje u tekstu: Ustavni sud) izraženima u njegovoj odluci br. U-I-763/2009 i dr. od 30. ožujka 2011.:

„16. Ustavna jamstva ... usmjerena su u prvom redu zaštiti prava i sloboda pojedinaca ili društvenih skupina ili pak zaštiti određenih odnosa koji čine društveno-gospodarski temelj društva ili njegovu nadgradnju. Ona

1 Usp. Kofler, G., Poiares Maduro, M., Pistone, P. (ur.), Human Rights and Taxation in Europe and the World, IBFD, Amsterdam, 2011., str. xxi. 
nisu izraz osobnosti i ljudskog dostojanstva pojedinca, već izraz preuzete obveze države skrbiti o određenom pravu ili slobodi pojedinca ili društvene skupine ili određenom društvenom odnosu te im pružiti djelotvornu pravnu zaštitu. Ta se preuzeta obveza ugrađuje u temeljnu normu u obliku ustavnog jamstva države. Stoga se ustavna jamstva u pravilu prosuđuju u odnosu na putove djelotvornog ostvarenja i zaštite samog predmeta jamstva, ali i na djelotvornost institucija koje su odgovorne za njegovo ostvarenje i zaštitu.

Prava i slobode te odnosi koji su predmet ustavnog jamstva u pravilu nisu apsolutni, već su podložni općim ograničenjima koja su predviđena u članku 16. Ustava, ali i posebnim ograničenjima koja su imanentna samo pojedinim Ustavom zaštićenim dobrima, sadržanima u ustavnim odredbama kojima se ta dobra uređuju.“

Sukladno citiranome, za potrebe ovog rada pod ustavnim jamstvima poreznih obveznika podrazumijevat će se ustavna jamstva koja država jamči poreznim obveznicima. Ta ustavna jamstava nisu apsolutna, već su podložna ograničenjima. U prvom redu, riječ je o općim ograničenjima koja su propisana u članku 16. Ustava Republike Hrvatske (dalje u tekstu: Ustav) ${ }^{2}$ koji glasi:

„Slobode i prava mogu se ograničiti da bi se zaštitila sloboda i prava drugih ljudi, pravni poredak, javni moral i zdravlje.

Svako ograničenje slobode ili prava mora biti razmjerno naravi potrebe za ograničenjem u svakom pojedinom slučaju.“

Osim toga, postoje i posebna ograničenja koja se odnose samo na pojedina Ustavom zaštićena ljudska prava i temeljne slobode koji pripadaju i poreznim obveznicima, a sadržani su u ustavnim odredbama kojima se ta prava ili slobode uređuju. Tako se, primjerice, prema članku 50. stavku 2. Ustava, poduzetnička sloboda i vlasnička prava mogu ograničiti radi zaštite interesa i sigurnosti $\mathrm{RH}$, prirode, ljudskog okoliša i zdravlja ljudi.

Kada se promatra interakcija između oporezivanja i ustavnih jamstava, može se zapaziti da je njihov odnos dvojak. ${ }^{3}$ Kao najvažniji izvor državnih prihoda, porezima se pribavljaju sredstva nužna za podmirivanje javnih potreba. To znači da oporezivanje služi kao sredstvo za ostvarenje općih društvenih i pravnih vrijednosti neke države, uključujući i ljudska prava i temeljne slobode. ${ }^{4}$ Međutim, s druge strane, oporezivanje može dovesti i do ograničenja odnosno povreda određenih ljudskih prava i temeljnih sloboda i tom aspektu oporezivanja posvećeno je ovo istraživanje.

Ostvarenje i zaštita ustavnih jamstava poreznih obveznika proučavani su kroz postupke odnosno pravne puteve koje porezni obveznici imaju pravo pokretati u svrhu zaštite svojih ustavom zajamčenih prava i sloboda. Zbog opsežnosti teme,

Narodne novine broj 56/90., 135/97., 113/00., 28/01., 76/10. i 5/14.

3 Kofler, G., Pistone, P., „General Report“, u: Kofler, G., Poiares Maduro, M., Pistone, P. (ur.), op. cit. (bilj. 1), str. 11.

4 Usp. ibid. 
predmet ovog rada neće biti postupci apstraktne kontrole ustavnosti odnosno ustavnosudski postupci koji su se odnosili na prijedloge za ocjenu ustavnosti zakona koji uređuju poreze. Istraživanje je usmjereno na proučavanje poreznih postupaka u kojima su porezni obveznici podnosili tužbu upravnim sudovima protiv drugostupanjskih rješenja Ministarstva financija, ustavnu tužbu te, eventualno, zahtjev protiv Hrvatske pred Europskim sudom za ljudska prava (dalje u tekstu i: Europski sud). Upravna i sudska praksa istražit ce se putem analize objavljene prakse Europskog suda ${ }^{5}$ Ustavnog suda. ${ }^{6}$ Stoga ce rad biti podijeljen u tri glavna dijela. Prvo će se istražiti primjena Europske konvencije za zaštitu ljudskih prava i temeljnih sloboda ${ }^{7}$ (dalje u tekstu: Europska konvencija ili Konvencija) u poreznim stvarima, nakon čega će slijediti posebni osvrt na zahtjeve protiv Hrvatske koji su podneseni pred Europskim sudom. Zadnji dio rada odnosit će se na analizu prakse Ustavnog suda u poreznim stvarima od 1. siječnja 2015. do 1. rujna 2017. godine. ${ }^{8}$

\section{PRIMJENA EUROPSKE KONVENCIJE U POREZNIM STVARIMA}

U praksi Europskog suda za ljudska prava pokazalo se da se podnositelji zahtjeva pozivaju na odredbe Europske konvencije za zaštitu ljudskih prava i temeljnih sloboda (dalje u tekstu: Europska konvencija ili Konvencija) kako bi osporili odluke visokih ugovornih stranaka u poreznim stvarima i postupke njihovih poreznih tijela. ${ }^{9}$ Zahtjevi podnositelja u predmetima koji se odnose na oporezivanje temelje se najčešće na članku 1. Protokola br. 1 uz Konvenciju (zaštita vlasništva) i članku 6. Konvencije (pravo na pošteno suđenje). U nekim predmetima podnositelji zahtjeva pozivaju se i na druge odredbe Konvencije, primjerice na članak 8. (pravo na poštovanje privatnog i obiteljskog života), članak 14. (zabrana diskriminacije) te članak 2. Protokola br. 4 (sloboda kretanja).

\subsection{Zaštita vlasništva}

Porezi nesumnjivo predstavljaju ovlast države da zadire u vlasnička prava. Načelna stajališta Europskog suda citirao je Ustavni sud u svojoj odluci i rješenju broj: U-IP-3820/2009 i dr. od 17. studenoga 2009.:

\footnotetext{
5 Baza podataka $H U D O C$ koja omogućava pristup praksi Europskog suda dostupna je na internetskoj stranici: https://hudoc.echr.coe.int/.

6 Baza ustavnosudske prakse koja omogućava pristup ustavnosudskim aktima dostupna je na internetskoj stranici: https://www.usud.hr/hr/praksa-ustavnog-suda.

7 Konvencija za zaštitu ljudskih prava i temeljnih sloboda, Narodne novine - Međunarodni ugovori broj 18/97., 14/02., 14/02., 1/06.

8 Razdoblje koje će se analizirati ograničeno je zbog opširnosti teme.

9 V. European Court of Human Rights, Taxation and the European Convention on Human Rights, August 2017, http://www.echr.coe.int/Documents/FS_Taxation_ENG.pdf.
} 
„14.1. Europski sud polazi od načelnog stajališta da je svako oporezivanje prima facie miješanje u pravo na mirno uživanje vlasništva zajamčeno člankom 1. stavkom 1. Protokola br. 1 uz Konvenciju ..., budući da ono 'pogođenu osobu lišava imovine, to jest iznosa novca koji ona mora platiti' (presuda Velikog vijeća Europskog suda u predmetu Burden protiv Ujedinjenog Kraljevstva, 20. travnja 2008., zahtjev br. 13378/05, § 59.). Međutim, Konvencija ne lišava državu njezinih poreznih ovlasti: država ima pravo primijeniti zakone radi osiguranja plaćanja poreza. Takvo miješanje države u imovinu osoba općenito je opravdano na temelju članka 1. stavka 2. Protokola br. 1 uz Konvenciju, koji izrijekom propisuje 'pravo države da primijeni zakone koje smatra potrebnima da bi uredila upotrebu vlasništva u skladu s općim interesom ili za osiguranje plaćanja poreza ili drugih doprinosa ili kazni'. S aspekta nadzora koji provodi Europski sud 'države, u načelu, ostaju slobodne iznaći različita pravila u području porezne politike’ (presuda Burden, § 65.).

Ipak, Europski sud, slično kao i Ustavni sud u postupcima pokrenutim ustavnim tužbama, pridržava pravo sudske kontrole miješanja države putem poreznih mjera u privatnu imovinsku sferu pojedinaca u konkretnim slučajevima, 'budući da je pravilna primjena članka 1. Protokola br. 1 predmet njegova nadzora' (presuda Burden, § 59.).“10

U predmetima u kojima ocjenjuje povredu članka 1. Protokola br. 1, Europski sud prvo ispituje odnose li se pobijane odluke na 'imovinu' (vlasništvo) podnositelja zahtjeva u smislu te odredbe. Pojam 'vlasništvo' ima autonomno značenje koje je u svojoj praksi izgradio Europski sud te je ono neovisno o tom pojmu u domaćim pravnim porecima visokih ugovornih stranaka. ${ }^{11}$ Nakon toga slijedi ispitivanje je li bilo miješanja u imovinu (vlasništvo) podnositelja zahtjeva. Europski sud oporezivanje smatra kontrolom korištenja imovinom u smislu stavka 2. članka 1. Protokola br. $1 .{ }^{12}$ Zadnji korak u tehnici ispitivanja povrede jest ispitivanje opravdanosti miješanja u pravo vlasništva. ${ }^{13}$ Pitanja koja Europski sud u okviru testa opravdanosti ispituje jesu sljedeća:

- je li miješanje bilo u skladu s načelima vladavine prava i zakonitosti,

- ako jest, je li miješanje imalo legitiman cilj u općem ili javnom interesu,

- $\quad$ ako jest, je li postignuta pravedna ravnoteža između općeg ili javnog interesa zajednice i zaštite imovinskih prava pojedinca. ${ }^{14}$

10 Detaljnije o predmetu Burden protiv Ujedinjenog Kraljevstva v. poglavlje 2.4. ovog rada.

11 V. Omejec, J., Konvencija za zaštitu ljudskih prava i temeljnih sloboda u praksi Europskog suda za ljudska prava - Strasbourški acquis, drugo dopunjeno izdanje, Novi informator, Zagreb, 2014., str. 953-954.

12 Ibid., str. 987.

13 V. detaljnije: ibid., str. 990.

14 Ibid. 
Slučajevi u kojima je Europski sud utvrdio povredu članka 1. Protokola br. 1 primjerice su S.A. Dangeville protiv Francuske (zahtjev br. 36677/97, presuda od 16. travnja 2002.), Buffalo S.r.l. u likvidaciji protiv Italije (zahtjev br. 38746/97, presuda od 3. srpnja 2003.), Eko-Elda AVEE protiv Grčke (zahtjev br. 10162/02, presuda od 9. ožujka 2006.), Intersplav protiv Ukrajine (zahtjev br 803/02, presuda od 9. siječnja 2007.), "Bulves” AD protiv Bugarske (zahtjev br. 3991/03, presuda od 22. siječnja 2009.), di Belmonte protiv Italije (zahtjev br. 72638/01, presuda od 16. ožujka 2010.), OAO Neftyanaya Kompaniya YUKOS protiv Rusije (zahtjev br. 14902/04, presuda od 20. rujna 2011.) te N.K.M. protiv Mađarske (zahtjev br. 66529/11, presuda od 14. svibnja 2013.).

\subsection{Pravo na pošteno suđenje}

U presudi Ferrazzini protiv Italije (zahtjev br. 44759/98, presuda velikog vijeća od 12. srpnja 2001.), veliko vijeće je razmotrilo potpadaju li porezne stvari pod članak 6. stavak 1. Konvencije te je utvrdilo da su porezni postupci izvan dosega članka 6. stavka 1. (ne spadaju pod građanska prava i obveze). ${ }^{15}$ Pravno stajalište Europskog suda je sljedeće:

„29. ... Sud smatra da su porezna pitanja još uvijek dio čvrste jezgre prerogativa javne vlasti, u kojima i dalje prevladava javna priroda odnosa između poreznih obveznika i zajednice. ... Smatra da porezni sporovi izlaze izvan okvira građanskih prava i obveza, unatoč imovinskim učincima koje nužno proizvode za poreznog obveznika.“16

Međutim, Europski sud smatra da se članak 6. može primijeniti na postupke vezane uz naplatu poreznih globa koji potpadaju pod kaznenu glavu članka $6 .{ }^{17}$

\subsection{Pravo na poštovanje privatnog i obiteljskog života}

Pojam 'doma', koji se štiti člankom 8. Europske konvencije, Europski je sud protumačio na način da se odnosi i na prostorije u kojima osoba obavlja svoju profesiju. Povredu prava na poštovanje privatnog i obiteljskog života Europski sud je utvrdio u predmetu André i drugi protiv Francuske (zahtjev br. 18603/03, presuda od 24. srpnja 2008.). Riječ je bila o pretrazi odvjetničkog ureda koju je obavila porezna inspekcija u svrhu pribavljanja dokaza protiv stranke odvjetnika (trgovačkog društva) i tijekom koje su oduzeti određeni osobni dokumenti odvjetnika. Europski sud je svoje stajalište o povredi članka 8. zaključio na sljedeći način:

„46. Na kraju, i najvažnije, Sud primjećuje da je svrha pretrage bila otkriti u prostorijama podnositelja zahtjeva, samo u njihovom svojstvu odvjetnika društva osumnjičenog za prijevaru, dokumente koji bi mogli

15 Ibid., str. 760-761.

16 Prijevod cit. prema: ibid., str. 761.

17 Ibid. str. 783-784. 
utvrditi postojanje takve prijevare od strane društva i upotrijebiti te dokumente kao dokaze protiv njega. Podnositelji zahtjeva ni u kojem trenutku nisu bili optuženi niti osumnjičeni da su počinili prekršaj niti da su bili uključeni u bilo kakvu prijevaru koju je počinio njihov klijent. 47. Sud, stoga, primjećuje da su u ovom slučaju, u okviru poreznog nadzora u poslove društva koje je bilo klijent podnositelja zahtjeva, tijela vlasti ciljala podnositelje zahtjeva samo zato što su imala poteškoća u izvršavanju potrebnog poreznog nadzora i traženju "računovodstvenih, pravnih ili korporativnih dokumenata" koji bi mogli potvrditi njihovu sumnju da je društvo krivo za utaju poreza.

48. U tom kontekstu, Sud utvrđuje da su, u okolnostima slučaja, pretraga i zapljena izvršene u prostorijama podnositelja zahtjeva bile nerazmjerne cilju koji se želi postići.“

\subsection{Zabrana diskriminacije}

U već spomenutoj presudi Burden protiv Ujedinjenog Kraljevstva (zahtjev br. 13378/05, presuda velikog vijeća od 29. travnja 2008.), podnositeljice zahtjeva bile su starije, neudate sestre koje su zajedno živjele tijekom cijelog svog života, a posljednjih 30 godina živjele su u svojoj kući koja je bila izgrađena na nekretnini naslijeđenoj od roditelja. Obje sestre napravile su oporuku kojom su jedna drugoj ostavile sve svoje nasljedstvo. Sestre su prigovarale tome što će se, kada jedna od njih umre, druga sestra morati suočiti s teškim poreznim zakonom o nasljedstvu, za razliku od preživjelog bračnog druga ili partnera životnog partnerstva koji su oslobođeni tog poreza u slučaju smrti svog bračnog druga ili partnera. ${ }^{18}$

Sud je utvrdio da se podnositeljice zahtjeva, kao sestre koje zajedno žive, nisu mogle usporediti u smislu članka 14. (zabrana diskriminacije) Konvencije s bračnim drugovima ili partnerima iz civilnog partnerstva, te je stoga smatrao da nije došlo do povrede članka 14. u vezi s člankom 1. Protokola br. 1. Na takav stav Europskog suda nije utjecala činjenica da je 47 država članica Vijeća Europe usvojilo niz različitih pravila vezanih za nasljeđivanje koja se odnose na preživjele bračne drugove, partnere iz civilnog partnerstva i one u bliskoj obiteljskoj vezi te je usvojilo različite politike u pogledu oslobađanja od poreza na nasljedstvo koje se odnosi na različite kategorije osoba (par. 65. presude). Države, u načelu, ostaju slobodne razvijati različita pravila u području politike oporezivanja (par. 66. presude).

\subsection{Sloboda kretanja}

U predmetu Reiner protiv Bugarske (zahtjev br. 46343/99, presuda od 23. svibnja 2006.), koji se odnosio na zabranu putovanja podnositeljice zbog poreznog duga i oduzimanja putovnice, Europski sud je osobito istaknuo da javni interes za naplatu

18 Sažetak predmeta prezentiran prema: European Court of Human Rights, op. cit. (bilj. 9), str. 17-18. 
neplaćenog poreza značajnog iznosa može opravdati odgovarajuća ograničenja prava podnositeljice zahtjeva. Države imaju određenu slobodu procjene kako bi oblikovale i organizirale svoje fiskalne politike i uredile osiguranje plaćanja poreza. Međutim, iz načela proporcionalnosti proizlazi da ograničenje prava na izlazak iz zemlje zbog neplaćenog duga može biti opravdano samo ako to služi njegovu cilju - naplati duga. To znači da takvo ograničenje ne može predstavljati de facto kaznu zbog nemogućnosti plaćanja. Nadalje, tijela vlasti nemaju pravo zadržati dulje razdoblje ograničenja slobode kretanja pojedinca bez periodičnog ponovnog procjenjivanja njegova opravdanja u svjetlu faktora poput toga jesu li fiskalne vlasti učinile razumne napore za prikupljanje duga drugim sredstvima i vjerojatnosti da dužnikovo napuštanje zemlje može onemogućiti naplatu. Međutim, u ovom predmetu, Sud je primijetio da tijela vlasti nisu uzele u obzir načelo razmjernosti u svojim odlukama i da je zabrana putovanja za podnositeljicu bila automatska i neodređenog trajanja. Nadalje je istaknuo da je osporena mjera trajala dugo i da je bila nerazmjerna cilju radi kojeg je izrečena, a to je da se naplati porezni dug. U ovom predmetu, osim što je utvrdio da je došlo do povrede članka 2. Protokola br. 4, Sud je također utvrdio da je došlo do povrede članka 13. (pravo na djelotvorno pravno sredstvo) u vezi s člankom 8. (pravo na poštovanje privatnog i obiteljskog života) i članka 2. Protokola br. 4 glede zabrane putovanja. ${ }^{19}$

\section{HRVATSKI SLUČAJEVI U POREZNIM STVARIMA PRED EUROPSKIM SUDOM}

Zasada se malo postupaka u poreznim stvarima vodi protiv Hrvatske pred Europskim sudom za ljudska prava. Četiri predmeta su u tijeku: Nogolica protiv Hrvatske (zahtjev br. 1375/14), Bogović protiv Hrvatske (zahtjev br. 44657/14), Turkalj protiv Hrvatske (zahtjev br. 55630/14) i Bežanić protiv Hrvatske (zahtjev br. 16140/15), a samo je jedan dosad presuđen (Guberina protiv Hrvatske, zahtjev br. 23682/13, presuda od 22. ožujka 2016.). U sva četiri spomenuta postupka koja su u tijeku Europski sud će ispitivati je li došlo do povrede prava vlasništva, a u tri od njih (Nogolica, Bogović i Turkalj) ispituje se još i povreda članka 13. koji jamči pravo na djelotvoran pravni lijek, koji glasi:

„Svatko čija su prava i slobode koje su priznate u ovoj Konvenciji povrijeđene ima pravo na djelotvorna pravna sredstva pred domaćim državnim tijelom čak i u slučaju kad su povredu počinile osobe koje su djelovale u službenom svojstvu.“

U predmetima Nogolica i Bogović radi se o pitanju zastare prava na utvrđivanje porezne obveze. Gospodin Nogolica u lipnju 2002. godine kupio je nekretninu u Resniku te je podnio prijavu prometa nekretnina u studenome iste godine. Porezna uprava, Područni ured Zagreb, 27. travnja 2007. godine utvrdila je da podnositelj zahtjeva mora platiti porez u iznosu od 39.096,00 kuna. Na porezno rješenje

19 Sažetak predmeta prezentiran prema: ibid., str. 19-20. 
podnositelj zahtjeva izjavio je žalbu, koju je 28. travnja 2010. godine Ministarstvo financija odbilo. Protiv rješenja drugostupanjskog tijela podnositelj je podnio tužbu Upravnom sudu Republike Hrvatske (od 2012. godine: Visoki upravni sud Republike Hrvatske). U njoj je tvrdio da je drugostupanjsko rješenje nezakonito iz razloga što je doneseno nakon što je 1. siječnja 2009. nastupila zastara utvrđivanja porezne obveze. Pozivao se na odredbu tadašnjeg Općeg poreznog zakona sukladno kojoj apsolutni rok zastare prava poreznog tijela na utvrđivanje porezne obveze nastupa za šest godina računajući od dana kada je zastara počela prvi put teći. U ožujku 2013. godine Visoki upravni sud odbio je njegovu tužbu s obrazloženjem da je podnositelj propustio prigovor zastare istaknuti u žalbi protiv prvostupanjskog rješenja Porezne uprave. U svibnju 2013. godine podnositelj je podnio ustavnu tužbu koju je Ustavni sud u lipnju iste godine odbacio s obrazloženjem da ne postoje pretpostavke za odlučivanje o biti stvari. Ustavni sud je ponovio da Visoki upravni sud nije razmatrao istaknuti prigovor zastare iz razloga što podnositelj taj prigovor ne može prvi put isticati u tužbi. Prema pravnom stajalištu Ustavnog suda, podnositelj u ustavnoj tužbi nije pokazao da Visoki upravni sud u postupanju ili pri donošenju odluke nije poštovao odredbe Ustava o ljudskim pravima i temeljim slobodama, odnosno da je proizvoljno protumačio mjerodavne odredbe zakona ili drugih propisa. Ustavni sud stoga je ocijenio da konkretan slučaj ne otvara pitanje ostvarenja ustavnih prava podnositelja te da, stoga, ne postoji ustavnopravna bit stvari o kojoj bi Ustavni sud odlučivao. ${ }^{20}$

U predmetu Nogolica Europski sud ispitivat će je li, s obzirom na odluku kojom se utvrđuje porezna obveza, došlo do povrede prava podnositelja na mirno uživanje vlasništva te je li podnositelj imao na raspolaganju djelotvorno pravno sredstvo koje zahtijeva odredba članka 13. Konvencije. ${ }^{21}$

U predmetu Bogović koji se isto odnosi na pitanje zastare, prvostupanjsko rješenje Porezne uprave, Područnog ureda Rijeka, doneseno je 29. veljače 2008. godine, a drugostupanjsko rješenje kojim je odbijena žalba podnositelja 21. rujna 2010. Zastara prava na utvrđivanje porezne obveze u ovom slučaju nastupila je 1. siječnja 2009. Protiv drugostupanjskog rješenja podnositelj je podnio tužbu u kojoj je tvrdio da prvostupanjska odluka nije bila konačna i da je porezna obvezna utvrđena tek drugostupanjskim rješenjem koje je doneseno nakon nastupa apsolutne zastare. Paralelno s ovim sporom, podnositelj je podnio zahtjev u zasebnom upravnom postupku u kojem je od prvostupanjskog tijela tražio da donese rješenje kojim bi se utvrdilo da je nastupila zastara. I taj je postupak završio nepovoljno za podnositelja zahtjeva. Visoki upravni sud odbio je obje tužbe podnositelja s obrazloženjem da drugostupanjsko rješenje nije nezakonito jer je porezna obveza utvrđena prvostupanjskim rješenjem koje je doneseno 29. veljače 2008. odnosno prije nastupa apsolutne zastare. Protiv obje presude Visokog upravnog suda

20 Rješenje Ustavnog suda broj: U-III-2577/2013 od 6. lipnja 2013.

21 European Court of Human Rights, Application no. 1375/14 Zvonko NOGOLICA against Croatia lodged on 18 December 2013, Statement of facts, Communicated on 29 March 2016, https://hudoc.echr. coe.int/. 
podnositelj je podnio ustavne tužbe koje su odbačene s jednakim obrazloženjem da ne postoje pretpostavke za odlučivanje o biti stvari. ${ }^{22}$

Europski će sud u predmetu Bogović utvrđivati je li praksa domaćih sudova u pogledu računanja apsolutne zastare u poreznim stvarima bila konzistentna te je li presuda Visokog upravnog suda bila u skladu s tumačenjem koje je zauzeo Vrhovni sud Republike Hrvatske u svojoj presudi broj: Uzz 31/11 od 18. studenoga 2014. U toj je presudi Vrhovni sud istaknuo da se...

„... u situaciji kad je protiv prvostupanjskog rješenja dopuštena žalba, ne može smatrati da je već donošenjem prvostupanjskog rješenja konačno odlučeno o pravu i obvezi stranke, jer se tek propuštanjem podnošenja žalbe ili donošenjem rješenja drugostupanjskog tijela povodom žalbe odbacivanjem žalbe, odbijanjem žalbe ili izmjenom rješenja (čl. 239. ZUP-a) dovršava postupak donošenja upravnog akta. ... Budući da je tuženo tijelo propustilo ocijeniti da je nastupila apsolutna zastara prava na utvrđivanje porezne obveze, to je donošenjem drugostupanjskog rješenja povrijeđen zakon na štetu tužitelja.“

U slučaju da Europski sud utvrdi da je praksa bila nekonzistentna ili da je presuda Visokog upravnog suda bila protivna gore navedenoj presudi Vrhovnog suda, ${ }^{23}$ dalje ce ispitati je li miješanje u pravo vlasništva podnositelja bilo u skladu sa zakonom kao što to zahtijeva članak 1. Protokola br. 1 uz Konvenciju te, osobito, je li takvo miješanje bilo predvidivo. Ako je bilo zakonito, ispitat će u idućem koraku je li bilo nužno za osiguranje naplate poreza. Osobito je zanimljivo da Europski sud zanima i je li porezni postupak predugo trajao (10 godina) i je li time povrijeđen, ne članak 6. stavak 1. (jer se on ne primjenjuje), već članak 13. (pravo na djelotvorno pravno sredstvo) u vezi s člankom 1. Protokola br. 1 (pravo vlasništva) ili pozitivne obveze države koje ona ima temeljem članka 1. Protokola br. $1 .{ }^{24}$

U predmetu Turkalj riječ je o nejasno napisanoj izreci u poreznom rješenju zbog koje je porezni obveznik smatrao da mu je porezni dug otpisan, ${ }^{25}$ a u predmetu Bežanić spor se vodio oko pitanja dovodi li promjena prebivališta do gubitka prava na poreznu olakšicu radi kupnje prve nekretnine kojom se rješava stambeno pitanje. Naime, Ustavni sud je u odluci broj: U-III-1311/2014 od 17. srpnja 2015. zauzeo pravno stajalište da...

22 Rješenja Ustavnog suda broj: U-III-269/2014 i U-III-270/2014 od 26. veljače 2014.

23 S tim u vezi, Europski je sud naveo da je Visoki upravni sud 13. studenoga 2015. i 4. ožujka 2016. donio dva zaključka, br. Su-424/2015 i br. Su-122/2016. Zaključak iz studenoga 2015. glasi: „Ostaje se kod dosadašnje prakse po kojoj se porezna obveza utvrđuje prvostupanjskim poreznim rješenjem. Od donošenja prvostupanjskog poreznog rješenja do donošenja rješenja po žalbi relativna zastara ne teče, već samo apsolutna“, a zaključak iz ožujka 2016. glasi: „Drugostupanjsko rješenje kojim je odbijena žalba protiv prvostupanjskog rješenja o utvrđivanju porezne obveze nije nezakonito zato što je doneseno nakon nastupa apsolutnog roka zastare.“

${ }^{24}$ European Court of Human Rights, Application no. 44657/14 Gojko BOGOVIĆ against Croatia lodged on 12 June 2014, Statement of facts, Communicated on 1 September 2016, https://hudoc.echr.coe. int/.

25 European Court of Human Rights, Application no. 55630/14, Marijan TURKALJ against Croatia lodged on 1 August 2014, Statement of facts, Communicated on 30 June 2016, https://hudoc.echr.coe.int/. 
,... tumačenje koje je izrazio Upravni sud, prema kome je dovoljna naknadna promjena prebivališta da se poreznom obvezniku (podnositelju) ne bi odobrilo porezno oslobođenje, ne proizlazi iz mjerodavnih odredbi ZoPPN" ${ }^{26}$

Slično tome, Vrhovni sud je u svojoj presudi broj: U-zpz 3/2014-5 od 29. listopada 2014. zauzeo sljedeće pravno shvaćanje:

„Prema pravnom shvaćanju ovoga suda, trenutak nastanka porezne obveze kod stjecanja nekretnine jasno je određen Zakonom o porezu na promet nekretnina. Porezna obveza nastaje, u smislu navedenih pravila, u trenutku sklapanja ugovora, odnosno drugoga pravnog posla kojim se stječe nekretnina. Kako se porezna osnovica te visina porezne obveze utvrđuju prema činjenicama koje su postojale u trenutku stjecanja nekretnine, to su i za oslobođenje od plaćanja poreza na promet nekretnina pravno relevantne one činjenice koje su postojale u trenutku u kojem porezna obveza nastaje, neovisno o tome kada je prijava poreza podnesena."

Uzimajući u obzir navedenu praksu, potrebno je utvrditi zašto je u odnosu na gospodina Bežanića donesena odluka kojom mu je određena porezna obveza. Europski sud će stoga ispitati je li podnositelju tom odlukom povrijeđeno pravo na mirno uživanje vlasništva osobito s obzirom na gore citiranu odluku Ustavnog suda i Vrhovnog suda. ${ }^{27}$

Značaj predmeta Guberina ogleda se, između ostalog, u tome što je riječ o jedinom dosad presuđenom predmetu pred Europskim sudom za ljudska prava koji se direktno odnosio na porezne stvari. Europski sud za ljudska prava donio je presudu kojom je utvrdio da je došlo do povrede članka 14. Konvencije u vezi s člankom 1. Protokola br. 1. Naime, podnositelj je zatražio od Ispostave Samobor Porezne uprave oslobođenje od plaćanja poreza na promet nekretnina prigodom kupnje kuće u Samoboru.

„U zahtjevu za oslobođenje od poreza podnositelj je naveo da kuću kupuje kako bi pribavio svom djetetu, stopostotnom invalidu, odgovarajući životni prostor. Stan u kojem je njegova obitelj do tada živjela nalazi se na trećem katu, u zgradi bez lifta, zbog čega je podnositelju bilo iznimno teško izvesti svoje dijete iz zgrade.

Podnositelj je svoj zahtjev zasnovao na zakonskoj odredbi koja dopušta oslobođenje od plaćanja poreza na promet nekretnina u slučaju da stjecatelj nekretnine kupuje prvu nekretninu radi rješavanja svojih stambenih potreba, a u vlasništvu nema drugu nekretninu (stan ili kuću) koja zadovoljava njegove stambene potrebe. Porezne vlasti su takav zahtjev odbile, obrazloživši svoju odluku činjenicom da je podnositeljev stan svojom površinom bio dovoljno velik za cijelu njegovu obitelj, te da je

26 Skraćenica ZoPPN odnosi se na Zakon o porezu na promet nekretnina, Narodne novine broj 69/97., 26/00. i 153/02.

27 European Court of Human Rights, Application no. 16140/15 Aleksandar BEŽANIĆ against Croatia lodged on 27 March 2015, Statement of facts, Communicated on 15 June 2017, https://hudoc.echr. coe.int/. 
taj stan imao svu potrebnu infrastrukturu poput vode, struje, kanalizacije i drugih komunalija.

Europski sud za ljudska prava je utvrdio da su porezne vlasti, bez razumnog i dostatnog objašnjenja, odbile uzeti u obzir specifičnost tužiteljevih stambenih potreba, imajući u vidu teški invaliditet njegovog djeteta. Time je tužitelj diskriminiran u odnosu na sve druge osobe koje stječu nekretninu radi zadovoljenja svojih stambenih potreba, te su oslobođene poreza na promet nekretnina ako postojeća nekretnina ne zadovoljava njihove stambene potrebe. ${ }^{\text {“2 } 28}$

\section{PRAKSA USTAVNOG SUDA U POREZNIM STVARIMA}

U statistički prikaz koji slijedi glede prakse Ustavnog suda uvrštene su samo one ustavne tužbe u poreznim stvarima od 1. siječnja 2015. do 1. rujna 2017. o kojima je Ustavni sud meritorno odlučivao (je li bilo povrede ljudskih prava i temeljnih sloboda ili ne). Istraživanjem je obuhvaćeno 85 odluka Ustavnog suda Republike Hrvatske (od 1 siječnja 2015. do 1. rujna 2017.) čiji se popis nalazi u prilogu 1. uz ovaj rad.

Postoji još veći broj ustavnih tužbi koje Ustavni sud odbacuje i one nisu prikazane u ovom statističkom prikazu. Prema podacima Ustavnog suda o pregledu primljenih i riješenih ustavnih tužbi od 1991. godine do 31. XII. 2016., 52,49 \% ustavnih tužbi bilo je odbačeno. Što se tiče podataka o načinu rješavanja predmeta od 01. I. do 31. XII. 2016., 68,07 \% ustavnih tužbi je bilo odbačeno. ${ }^{29}$ Tako je, primjerice, i u predmetima Bogović i Nogolica koji se trenutno nalaze u postupku pred Europskim sudom, Ustavni sud odbacio ustavne tužbe podnositelja. Ustavni sud je smatrao da u ustavnoj tužbi tužitelji ne navode niti jedno bitno ustavnopravno pitanje te da ne obrazlažu navodno postojanje povreda ustavnih i konvencijskih prava.

Vezano za odluke Ustavnog suda koje su obuhvaćene ovim radom, istraživanjem je utvrđeno da je 2015. godine odbijeno $63,2 \%$, a usvojeno $36,8 \%$ ustavnih tužbi u poreznim stvarima. Dakle, Ustavni sud te je godine usvojio nešto malo više od jedne trećine ustavnih tužbi, a odbio ih je oko dvije trećine. Godine 2016. odbijeno je $80 \%$, a usvojeno $20 \%$. To znači da bi tek svaka peta ustavna tužba u poreznim stvarima bila usvojena. Veliki broj predmeta u kojima su ustavne tužbe bile odbijene te godine odnosio se na odgovornost poreznih jamaca zbog utvrđenih zlouporaba. U 2017. godini (do rujna) usvojeno je 73,1 \%, a odbijeno $26,9 \%$ ustavnih tužbi. S obzirom na to da je u 2016. godini u ukupnom broju riješenih predmeta usvojeno tek $2,25 \%$, vidljivo je da se radi o zapanjujuće velikom povećanju usvajanja ustavnih tužbi. Razlog zašto je došlo do toga jest u tome što je u veljači 2017. godine Ustavni

28 Ured zastupnika Republike Hrvatske pred Europskim sudom za ljudska prava, Nova presuda - Guberina protiv Hrvatske, Diskriminacija zbog odbijanja poreznog oslobođenja, objavljeno: 22. III. 2016., https://uredzastupnika.gov.hr/vijesti/nova-presuda-guberina-protiv-hrvatske/282.

29 Autorica zahvaljuje Sanji Trgovac, voditeljici Centra za evidenciju i dokumentaciju Ustavnog suda Republike Hrvatske na dostavljenim podacima. 
sud donio odluku kojom je izjednačio izvanbračne drugove s bračnima u pogledu primjene poreznih zakona. Riječ je odluci broj: U-III-3034/2012 od 21. veljače 2017. Ta je odluka postala vodeći 'pilot' slučaj na temelju kojeg je, zasnivajući svoju odluku na istim razlozima koji su navedeni i obrazloženi u toj odluci, Ustavni sud i u drugim istovrsnim predmetima utvrdio povredu ustavnih prava podnositelja. Ustavni sud je obrazložio da su u zakonodavnom poretku Republike Hrvatske nastupile bitne promjene u pristupu izvanbračnoj zajednici u smislu izjednačavanja položaja osoba s obzirom na njihov bračni odnosno izvanbračni status. Iz tog razloga Ustavni sud nije mogao više prihvaćati upravnu i sudsku praksu uskog tumačenja pojma bračni drug u raznim poreznim zakonima. Ustavni sud je tako utvrdio da je došlo do diskriminacije izvanbračnih drugova u usporedbi s bračnim drugovima prilikom primjene odredbi o oslobađanju od plaćanja poreza na promet nekretnina i poreza na nasljedstva i darove te kod utvrđivanja poreza na dohodak odnosno kod priznavanja osobnog odbitka za uzdržavanog člana uže obitelji koji je izvanbračni drug.

U postupcima u kojima je Ustavni sud razmatrao štite li se ustavna jamstva u poreznim postupcima, slučajeve je u najvećem broju predmeta ispitivao s aspekta prava na pravično suđenje. U tom kontekstu, nužno je istaknuti značajnu razliku između Europske konvencije i hrvatskog Ustava, a to je da se pravo na pravično suđenje prema Ustavu odnosi na sve upravne sporove, za razliku od Europske konvencije koja jamči to pravo samo kada se odlučuje o građanskim pravima ili obvezama. Dakle, porezni postupci prema hrvatskom Ustavu potpadaju pod doseg zaštite članka 29. stavka 1. Ustava i u tom smislu hrvatski Ustav pruža širu zaštitu od Europske konvencije.

U predmetima u kojima bi Ustavni sud utvrdio povredu prava na pravično suđenje, često bi istaknuo i da je došlo i do povrede članka 19. stavka 2. Ustava koji jamči sudsku kontrolu zakonitosti pojedinačnih akata uprave.

U predmetima koji su se odnosili na izvanbračne drugove utvrdio je povredu zabrane diskriminacije u vezi s pravom vlasništva, a zanimljivo je da je u jednom od tih slučajeva (odluka Ustavnog suda broj: U-III-6416/2012 od 27. lipnja 2017.) također napomenuo da su povrijeđena načela jednakosti i pravednosti iz članka 51. Ustava na kojima se temelji porezni sustav.

\section{ZAKLJUČAK}

U praksi Ustavnog suda - osobito u prvoj polovini 2017. godine - došlo je do značajnog razvoja poreznog ustavnog prava u Hrvatskoj koje pokazuje da porezi nisu samo puki instrument za ubiranje sredstava za podmirenje javnih troškova, već je potrebno da se oporezivanjem ujedno ostvaruju vrijednosti koje su zajamčene Ustavom i Europskom konvencijom.

Istraživanjem je utvrđeno da je uspješnost ustavnih tužbi pojedinaca u poreznim stvarima mnogo veća u usporedbi s ustavnim tužbama koje podnose poduzetnici 
ili trgovačka društva. U 2015. godini pojedinci su bili uspješni u 83,3 \% predmeta, za razliku od poduzetnika i trgovačkih društava koji su postigli uspjeh u $30 \%$ predmeta. Međutim, i u 2016. godini i do rujna 2017. godine samo je po jedna usvojena ustavna tužba trgovačkog društva. Praksa Europskog suda pokazuje da su često trgovačka društva podnositelji zahtjeva protiv država, pa se s povećanjem svjesnosti o primjeni Europske konvencije u poreznim stvarima može očekivati i porast broja zahtjeva i protiv Hrvatske koje bi mogli podnositi poduzetnici i trgovačka društva. U tom smislu ce pozicija Hrvatske pred Europskim sudom za ljudska prava biti tim ,jača“ što će odluke sudova (prvostupanjske upravnih sudova te Visokog upravnog suda), uključujući i Ustavni sud, biti bolje obrazložene. Kao jedan od glavnih problema koji se aktualizirao u predmetima o kojima će Europski sud odlučivati (predmeti Bogović protiv Hrvatske i Bežanić protiv Hrvatske) jest neusklađena sudska praksa.

I naposljetku, Ustavni sud bi mogao razmotriti svoju praksu odbacivanja ustavnih tužbi zbog nepostojanja pretpostavki za odlučivanje o biti stvari. Naime, istraživanje je pokazalo da Europski sud u pojedinim slučajevima utvrđuje da su dopušteni oni predmeti koje Ustavni sud prethodno uopće nije meritorno razmatrao. Budući da i Europski sud ima ovlast proglasiti nedopuštenim svaki zahtjev koji smatra očito neosnovanim, a to u pogledu zahtjeva Bogović protiv Hrvatske i Nogolica protiv Hrvatske nije učinio, praksa Ustavnog suda, u tom kontekstu odbacivanja ustavnih tužbi, u nekim se slučajevima može doimati suviše šablonskom.

Prilog 1. Popis pregledane prakse Ustavnog suda Republike Hrvatske (od 1 siječnja 2015. do 1. rujna 2017.)

1. U-III-468/2014 - Jurlić, Tina, 05. VII. 2017., odbijanje

2. U-III-6416/2012 - Hančević, Janko, 27. VI. 2017., usvajanje

4. U-III-6077/2014 - Kardum, Pero, 14. VI. 2017., odbijanje

6. U-III-5054/2016 - Krtanjek, Dijana, 31. V. 2017., usvajanje

8. U-III-4679/2012 - Krušarovski, Zlata, 25. V. 2017., usvajanje

10. U-III-3757/2013 - Krušarovski, Zlata, 25. V. 2017., usvajanje

12. U-III-7021/2014 - Škorić, Božidar, 17. V. 2017., usvajanje

14. U-III-6080/2012 - Kelemen, Violeta, 11. V. 2017., usvajanje

16. U-III-343/2013 - Kovač, Kristijan, 11. V. 2017., usvajanje

18. U-III-5106/2012 - Kovačić, Vesna, 11. V. 2017., usvajanje

20. U-III-1553/2014 - Kapetanović, Nedjeljka, 04. V. 2017., usvajanje

22. U-III-2418/2009 - Špoljar, Marijela, 04. V. 2017., usvajanje

24. U-III-1631/2013 - Kelemen, Violeta, 04. V. 2017., usvajanje

26. U-III-4804/2013 - Renić, Ljiljana, 04. V. 2017., usvajanje

28. U-III-6045/2016 - Makovac, Lucija, 20. IV. 2017., usvajanje

30. U-III-2350/2014 - Marić, Ančica, 20. IV. 2017., odbijanje

32. U-III-1994/2014 - Strišković, Josip, 20. IV. 2017., odbijanje 
34. U-III-2760/2014 - Mustapić, Mirko, 20. IV. 2017., odbijanje

36. U-III-6288/2016 - RI-PETROL d.o.o., 20. IV. 2017., usvajanje

38. U-III-4137/2014 - Romb d.o.o., 20. IV. 2017., odbijanje

40. U-III-4525/2015 - Radetić, Ante, 20. IV. 2017., usvajanje

42. U-III-5348/2013 - Šimunić, Anka, 20. IV. 2017., usvajanje

44. U-III-2856/2013 - Bublić Grgin, Kristina, 13. IV. 2017., usvajanje

46. U-III-2035/2013 - Božić, Branko, 08. III. 2017., usvajanje

48. U-III-3034/2012 - Peyrek, Vojslav, 21. II. 2017., usvajanje

50. U-III-2417/2014 - Lucić, Franjo, 07. II. 2017., odbijanje

52. U-III-3810/2009 - TERMOPLIN d.o.o., 22. XII. 2016., odbijanje

54. U-III-7515/2014 - Soldo, Mladen, 22. XII. 2016., odbijanje

56. U-III-5307/2013 - Odvjetničko društvo Ruždjak i partneri j.t.d., 22. XII. 2016., odbijanje

58. U-III-2658/2015 - Civitas Nova d. d., 18. XI. 2016., odbijanje

60. U-III-2915/2014 - Vrba nekretnine d.o.o., 02. XI. 2016., odbijanje

62. U-III-603/2012 - Ivančić, Zdravko, 25. X. 2016., usvajanje

64. U-III-6657/2014 - Premilovac, Munib, 19. X. 2016., odbijanje

66. U-III-6292/2013 - SELEN STUDIO d.o.o., 13. X. 2016., odbijanje

68. U-III-2914/2014 - Tolić, Nada, 13. X. 2016., odbijanje

70. U-III-4772/2014 - Bagudić, Snježana, 13. X. 2016., odbijanje

72. U-III-1829/2014 - Krželj, Zoran, 28. IX. 2016., odbijanje

74. U-III-4244/2011 - Benić, Igor, 28. IX. 2016., odbijanje

76. U-III-4285/2013 - Valjalo Travaš, Armida, 27. IX. 2016., usvajanje

78. U-III-7668/2014 - Puškarić, Snježana, 27. IX. 2016., usvajanje

80. U-III-603/2014 - OSIJEK KOTEKS d. d., 21. IX. 2016., odbijanje

82. U-III-557/2014 - Vidović, Dino, 21. IX. 2016., odbijanje

84. U-III-4944/2014 - TROMONT d.o.o., 07. IX. 2016., odbijanje

86. U-III-4576/2014 - HALE-MONT NEKRETNINE d.o.o., 14. VII. 2016., odbijanje

88. U-III-2351/2013 - NHR Grupa d.o.o., 14. VII. 2016., odbijanje

90. U-III-378/2013 - FRANK BUS d. o. o., 30. VI. 2016., odbijanje

92. U-III-7108/2014 - Lovrić Dobroslavić, Dinka, 30. VI. 2016., odbijanje

94. U-III-456/2013 - Kordić, Zdenko, 29. VI. 2016., odbijanje

96. U-III-3955/2015 - Čirjak, Denis, 25. V. 2016., usvajanje

98. U-III-5006/2012 - JADRANSKO OSIGURANJE d.d., 19. V. 2016., odbijanje

100. U-III-1816/2015 - X. Z., 11. V. 2016., usvajanje

102. U-III-1984/2015 - X. Z., 11. V. 2016., usvajanje

104. U-III-1942/2015 - X. Z., 11. V. 2016., usvajanje

106. U-III-6430/2014 - Karamatić, Smiljan, 05. V. 2016., odbijanje

108. U-III-2394/2011 - Maroslavac, Željka, 04. V. 2016., odbijanje

110. U-III-1882/2015 - Građa d.d., 21. IV. 2016., odbijanje

112. U-III-6136/2014 - REGINEX d.o.o., 21. IV. 2016., odbijanje

114. U-III-5931/2014 - GRP MEDIA d.o.o., 13. IV. 2016., usvajanje 
116. U-III-3931/2013 - YACHTING KOMFOR d.o.o., 07. IV. 2016., odbijanje

118. U-III-7360/2014 - Lovričić, Ante, 30. III. 2016., odbijanje 120. U-III-4141/2014 - Budimir, Ante, 11. II. 2016., odbijanje 122. U-III-217/2015 - Kapular, Dragan, 28. I. 2016., odbijanje 124. U-III-3582/2012 - P.H.F. MONTAŽA d.o.o., 14. I. 2016., odbijanje 126. U-III-2524/2012 - Vujević, Stoja, 14. I. 2016., odbijanje 128. U-III-7680/2014 - Kosinec, Barica, 14. I. 2016., odbijanje 130. U-III-311/2013 - Berišić, Branko, 14. I. 2016., odbijanje 132. U-III-3908/2012 - ARCUS DALMATIA d.o.o., 19. XI. 2015., odbijanje 134. U-III-6465/2012 - Pavelić, Neven, 18. XI. 2015., usvajanje 136. U-III-4297/2012 - Sabalić, Jure, 23. IX. 2015., usvajanje 138. U-III-4296/2012 - Sabalić, Jure, 23. IX. 2015., usvajanje 140. U-III-4295/2012 - Sabalić, Ivo, 23. IX. 2015., usvajanje 142. U-III-296/2014 - Metal moneta d.o.o., 17. VII. 2015., usvajanje 144. U-III-1311/2014 - Mužić, Zoran, 17. VII. 2015., usvajanje 146. U-III-5892/2011 - STRABAG d. d., 27. V. 2015., odbijanje 148. U-III-1231/2014 - GEOPROJEKT d. o. o., 13. V. 2015., odbijanje 151. U-III-4274/2012 - Imex banka d.d. Split, 31. III., 2015., usvajanje 153. U-III-6670/2014 - Auto Lozić d.o.o., 05. III. 2015., odbijanje 155. U-III-5/2015 - Pauk Osijek d.o.o., 05. III. 2015., odbijanje 157. U-III-7236/2014 - Nemeth, Alojzije, 19. II. 2015., usvajanje 159. U-III-3109/2014 - Medvidović, Ana, 19. II. 2015., odbijanje 161. U-III-3113/2014 - Bagi d.o.o., 05. II. 2015., odbijanje 163. U-III-3110/2014 - Bagudić, Ivan, 05. II. 2015., odbijanje 165. U-III-3045/2014 - Lozić, Vjekoslav, 05. II. 2015., odbijanje 167. U-III-3069/2014 - Krov d.o.o., 05. II. 2015., odbijanje 169. U-III-7026/2014 - Sučec, Vlado, 22. I. 2015., odbijanje 


\section{PROTECTION OF CONSTITUTIONAL GUARRANTEES OF TAXPAYERS IN TAXATION PROCEDURES}

Creation and protection of constitutional guarantees of taxpayers are studied here through procedures, that is, legal means which taxpayers have the right to initiate in the aim of protecting their own constitutionally guaranteed rights and freedoms. Administrative and court practice is investigated by analysing the published practices of the European Court of Human Rights and the Constitutional Court of the Republic of Croatia. In this sense, this paper is divided into three main parts. Firstly, the application of the European Convention for the Protection of Fundamental Rights and Freedoms in taxation matters. This is followed by a special analysis of the cases against Croatia filed with the European Court. The last part is related to analysis of the practice of the Constitutional Court in taxation matters since 1 January 2015 till 1 September 2017 which includes 85 constitutional court decisions.

Key words: constitutional guarantees, taxpayer, taxation procedure, Constitutional Court of the Republic of Croatia, European Court of Human Rights 